\title{
TRANSFORMASI DATA HUJAN - DEBIT MENGGUNAKAN MODEL GR2M PADA DAS AIR DINGIN
}

\author{
Nika Rahma Yanti dan Rusnam \\ Program Studi Teknik Pertanian dan Biosistem, Fakultas Teknologi Pertanian, Universitas Andalas \\ E-mail: nikary@ae.unand.ac.id
}

\begin{abstract}
ABSTRAK
Pengelolaan sumberdaya air untuk masa yang akan datang sangat berkaitan dengan ketersediaan data. Terdapat beberapa model hidrologi yang telah dikembangkan untuk kegiatan pengelolaan DAS, salah satu model yang bisa digunakan adalah model GR2M. Penelitian ini bertujuan untuk melihat sensitivitas DAS Air Dingin terhadap perubahan curah hujan yang terjadi menggunakan model GR2M. Variabel utama yang dibutuhkan pada model ini adalah data curah hujan dan data evapotranspirasi. Penelitian ini dilaksanakan pada DAS Air Dingin dengan outlet debit yang tersedia pada DAS Air Dingin. Tahapan awal dalam pelaksanaan penelitian ini yakninya pengolahan data curah hujan,, evapotranspirasi bulanan, lalu penentuan parameter X1 (kapasitas simpanan kelembaban tanah) dan X2 (koefisien penyerapan air tanah), dilanjutkan tahapan kalibrasi serta validasi model. Hasil penelitian menunjukan pada tahapan kalibrasi diperoleh hasil koefisien deterministik $\left(\mathrm{R}^{2}\right)$ sebesar 0,7 dan koefisien efisiensi model Nash $(\mathrm{Q})$ sebesar 0,71 sehingga model GR2M mampu mempresentasikan DAS Air Dingin dengan kriteria memuaskan.
\end{abstract}

Kata kunci-DAS Air Dingin; evapotranspirasi; GR2M; model

\section{PENDAHULUAN}

Pergerakan air pada Daerah Aliran Sungai (DAS) merupakan sebuah proses dinamis yang sangat bergantung pada distribusi curah hujan, kombinasi tutupan lahan, kecepatan evapotranspirasi, jenis tanah, kelerengan serta pola jaringan sungai. Sehingga dari beberapa komponen ini akan meghasilkan sebuah proses dinamis yang kompleks (Arifjaya et al., 2012). Pengelolaan dan pengembangan sumber daya air pada dasarnya menyangkut modifikasi siklus hidrologi untuk mengatur penyediaan air alamiah hingga diperoleh kesetimbangan antara ketersediaan dan kebutuhan yang diperlukan manusia (Susanto, 2012).

Minimnya ketersediaan data dan dana telah menjadi kendala utama dalam pengembangan sumber daya air. Pada umumnya data yang tersedia pada suatu daerah adalah data hujan, diperlukan sebuah transformasi dari data hujan menjadi data debit. Salah satu model yang dapat digunakan yakninya model GR2M (Pratiwi et al., 2016). Terdapat beberapa model hidrologi terkait keseimbangan air yang telah dikembangkan, seperti NRECA, model Mock, ABCD dan lainnya. Berdasarkan penelitian yang telah dilakukan oleh Perez-Sanchez tahun 2019, dari 6 model neraca air yang diujikan, model GR2M merupakan model paling baik performanya dalam mendeskripsikan suatu DAS. GR2M (Global Rainfall-Run Off Model) adalah sebuah model sederhana yang dijalankan dengan data bulanan dua parameter iklim (curah hujan dan evapotranspirasi) serta data debit outlet DAS (Ibrahim et al., 2015).

DAS Air Dingin merupakan salah satu DAS di Kota Padang yang terletak pada Kecamatan Koto Tangah. Semenjak 18 April 2011 pusat pemerintahan Kota Padang secara resmi dipindahkan ke Kecamatan Koto Tangah untuk mengurangi kepadatan penduduk pada kawasan pantai serta percepatan pertumbuhan ekonomi Kota Padang (Rusnam, 2013). Penggunaan lahan DAS Air Dingin telah mengalami perubahan mulai dari tahun ke tahun, peningkatan tertinggi terdapat pada perumahan dan penurunan lahan paling siginifikan terjadi pada kawasan hutan (Allen, 2019). Jika hal ini terus menerus terjadi akan berakibat buruk pada ketersediaan air pada DAS Air Dingin, sehingga diperlukan perencanaan pengelolaan DAS Air Dingin untuk masa mendatang. DAS Air Dingin merupakan salah satu DAS yang memiliki rekapitulasi data yang lengkap, sehingga memungkinkan untuk melakukan pengujian kinerja suatu model. Penelitian ini bertujuan untuk menilai sensitivitas DAS Air Dingin terhadap perubahan curah hujan menggunakan model GR2M. 


\section{METODOLOGI PENELITIAN}

\section{A. Waktu dan Tempat}

Penelitian ini dilakukan di Daerah Air Sungai (DAS) Air Dingin Kota Padang. Pengolahan data dilaksanakan pada Laboratorium Teknik Sumber Daya Lahan dan Air, Fakultas Teknologi Pertanian, Universitas Andalas.

\section{B. Alat dan Bahan}

Alat yang digunakan dalam penelitian ini yaitu seperangkat komputer dengan perangkat lunak diantaranya Microsoft Excel, ArcGIS 10.4.1. Global positioning system (GPS), kamera digital serta alat penyimpan data.

Sebagai pendukung penelitian dibutuhkan beberapa data sekunder diantaranya : Peta administrasi Kota Padang, data DEM resolusi $30 \times 30 \mathrm{~m}$, data berupa data curah hujan stasiun bendung Koto Tuo, Gunung Nago, dan data debit DAS Air Dingin tahun 2007 - 2018 (PSDA Sumatera Barat). Data klimatologi berupa data temperatur minimum, temperatur maksimum, kelembaban, kecepatan angin serta lama penyinaran matahari berupa data harian tahun 2007 - 2018 (BMKG Stasiun Meteorologi Kelas II Minangkabau).

\section{Pelaksanaan Penelitian}

1. Pengolahan data hujan

Pengolahan data hujan dilakukan dengan mencari nilai hujan pada tiap bulan dengan sumber data beberapa stasiun penakar curah hujan. Perhitungan data hujan yang hilang menggikuti persamaan (1) dan Rata-rata hitung curah hujan persamaan (2) (Limantara, 2010).

$P_{x}=\frac{\sum_{i=1}^{n} \frac{P_{i}}{L i^{2}}}{\sum_{i=1}^{n} \frac{1}{l i^{2}}}$

keterangan:

Px : hujan yang hilang di stasiun $\mathrm{X}(\mathrm{mm})$

$\mathrm{Pi} \quad$ : data hujan di stasiun sekitarnya pada periode yang sama $(\mathrm{mm})$

$\mathrm{Li} \quad$ : jarak stasiun $\mathrm{X}$ dengan stasiun di sekitarnya $(\mathrm{km})$

$\mathrm{N} \quad$ : jumlah stasiun hujan disekitarnya

$d=\frac{d 1+d 2+d 3+\cdots+d n}{n}=\sum_{i=1}^{n} \frac{d n}{n}$.

keterangan :

$\mathrm{d}=$ tinggi curah hujan rata-rata daerah (DAS)

$\mathrm{d} 1, \mathrm{~d} 2, \ldots . \mathrm{dn}=$ Curah hujan pada pos penakar $1,2, \ldots ., \mathrm{n}$

$\mathrm{n}=$ banyaknya pos penakar

2. Evapotranspirasi

Penghitungan evapotranspirasi dengan metode Penman-Monteith, 1965 (BSN, 2004)

$E T_{o}=\frac{0,408 \Delta R_{n}+\gamma \frac{900}{(T+273)} U_{2}\left(e_{s}-e_{a}\right)}{\Delta+\gamma\left(1+0,34 U_{2}\right)}$.

keterangan:

ETo : evapotranspirasi tanaman acuan, (mm/hari).

$R_{n} \quad$ : radiasi matahari netto di atas permukaan tanaman, (MJ $/ \mathrm{m}^{2} /$ hari).

$\mathrm{T}$ : suhu udara rata-rata, $\left({ }^{\circ} \mathrm{C}\right)$.

$\mathrm{U}_{2}$ : kecepatan angin pada ketinggian $2 \mathrm{~m}$ dari atas permukaan tanah, $(\mathrm{m} / \mathrm{s})$.

$\mathrm{e}_{\mathrm{s}} \quad$ : tekanan uap air jenuh, $(\mathrm{kPa})$.

$\mathrm{e}_{\mathrm{a}}$ : tekanan uap air aktual, (kPa).

$\mathrm{D}$ : kemiringan kurva tekanan uap air terhadap suhu, $\left(\mathrm{kPa} /{ }^{\circ} \mathrm{C}\right)$

$\mathrm{g} \quad$ : konstanta psikrometrik, $\left(\mathrm{kPa} /{ }^{\circ} \mathrm{C}\right)$. 
3. Model GR2M

Menurut (Mouelhi, C., C. Michel., 2006), input utama model GR2M adalah data curah hujan bulanan dan data evapotranspirasi bulanan, seperti terlihat pada Gambar 1 berikut.

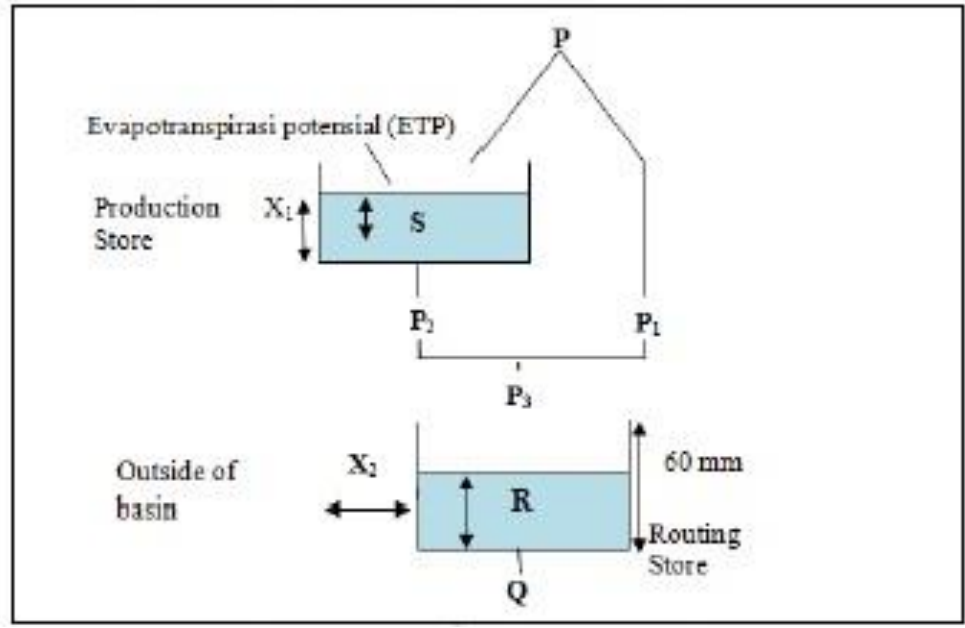

Gambar 1. Model GR2M

Persamaan yang digunakan dalam model GR2M (Mouelhi, 2006)

$S_{1}=\frac{S_{0}+X_{i \varphi}}{1+\varphi \frac{S}{X_{1}}}$.

$\varphi=\tanh \frac{p}{x_{1}}$.

$P_{1}=P+S_{0}-S_{1}$

$S_{2}=\frac{S_{1}(1-\psi)}{1+\psi\left(1-\frac{S_{1}}{X_{1}}\right)}$

$\psi=\tanh \frac{E T}{X_{1}}$

$S=\frac{S_{2}}{\left[1+\left(\frac{S_{2}}{X_{1}}\right)\right]^{1 / 8}}$

$P_{2}=S_{2}-S$

$P_{3}=P_{1}+P_{2}$

$R_{1}=R+P_{3}$

$R_{2}=X_{2}+R_{1}$

$Q=\frac{R_{2}^{2}}{R_{2}+60}$

keterangan:

S1 : kelengasan tanah akibat presipitasi ( $\mathrm{mm} / \mathrm{bulan})$,

S0 : kelengasan awal tanah ( $\mathrm{mm} /$ bulan) nilai kelengasan awal tanah untuk bulan pertama perhitungan maksimal sebesar X1, sedangkan nilai kelengasan awal tanah untuk bulan lain sebesar S pada bulan sebelumnya (mm/bulan),

$\mathrm{P}$ : curah hujan bulanan ( $\mathrm{mm} / \mathrm{bulan})$,

P1 : aliran permukaan ( $\mathrm{mm} / \mathrm{bulan})$,

$\mathrm{X} 1$ : kelengasan maksimum tanah (mm/bulan),

S2 : kelengasan tanah akibat presipitasi dan evapotranspirasi ( $\mathrm{mm} / \mathrm{bulan})$,

E : evapotranspirasi ( $\mathrm{mm} / \mathrm{bulan})$,

S3 : kelengasan tanah akibat infiltrasi ke lapisan tanah ( $\mathrm{mm} / \mathrm{bulan})$,

P2 : kedalaman hujan akibat pengurangan S2-S ( $\mathrm{mm} / \mathrm{bulan})$,

P3 : kedalaman hujan total $(\mathrm{P} 1+\mathrm{P} 2)(\mathrm{mm} / \mathrm{bulan})$,

$\mathrm{R}$ : nilai routing ( $\mathrm{mm} / \mathrm{bulan})$, nilai routing untuk bulan pertama perhitungan maksimal sebesar $60 \mathrm{~mm} /$ bulan, sedangkan nilai routing untuk bulan lain sebesar $\mathrm{R}$ pada bulan sebelumnya (mm/bulan) 
4. Kalibrasi dan validasi model

Kalibrasi model dilakukan dengan tujuan untuk melihat performa model apakah model dapat diaplikasikan pada DAS Air Dingin atau tidak. Uji performa model ini dilakukan terhadap data debit pada stasiun pengamatan. Penerapan suatu model hidrologi DAS tergantung kepada seberapa baik model tersebut pada saat kalibrasi. Nash-Sutcliffe merupakan salah satu referensi untuk permodelan hidrologi. Persamaan ini dapat memverifikasi kemampuan model untuk mereproduksi debit maksimum, debit minimum dan debit rata-rata (Traore, 2014). Kriteria evaluasi statistik model hidrologi yang dapat digunakan diantaranya koefisien deterministik $\left(\mathrm{R}^{2}\right)$ serta Nash-Sutcliffe (De Almeida et al. 2015).

$R^{2}=\left(\frac{\sum_{i}^{n}\left(Q_{o b s, i}-\overline{Q_{o b s}}\right)\left(Q_{s i m, i}-\overline{Q_{s i m}}\right)}{\sqrt{\sum_{i}^{n}\left(Q_{o b s, i}-\overline{Q_{o b s}}\right) \cdot \sum_{i}^{n}\left(Q_{s i m}, \overline{Q_{s t m}}\right)}{ }^{2}}\right) \ldots$

$\operatorname{Nash} Q=100\left[1-\frac{\sum\left(Q_{i}^{o b s}-Q_{i}^{s i m}\right)^{2}}{\sum\left(\overline{Q_{l}^{o b s}}-Q_{i}^{s i m}\right)^{2}}\right]$

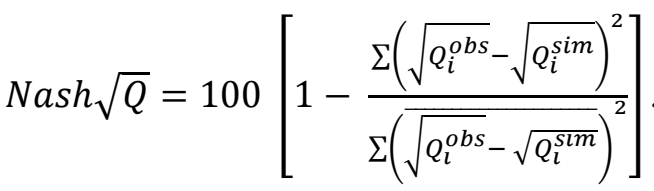

keterangan:

$Q_{i}^{\text {obs }} \quad$ : debit aktual yang terukur

$\underline{Q_{i}^{s i m}}:$ debit simulasi yang terukur

$\overline{Q_{l}^{\text {obs }}} \quad$ : debit aktual rata-rata

$\overline{Q_{l}^{s l m}} \quad$ : debit simulasi rata-rata

Tabel 1. Kriteria klasifikasi untuk model hidrologi (Pérez-Sánchez, Senent-Aparicio, Segura-Méndez, Pulido-Velazquez, \& Srinivasan, 2019)

\begin{tabular}{clcc}
\hline No & \multicolumn{1}{c}{ Kriteria } & $\mathrm{R}^{2}$ & Nash \\
\hline 1. & Sangat baik & $\mathrm{R}^{2} \geq 0,85$ & $0,75<$ Nash $\leq 1$ \\
2. & Baik & $0,75<\mathrm{R}^{2} \leq 0,85$ & $0,66<$ Nash $\leq 0,75$ \\
3. & Memuaskan & $0,60<\mathrm{R}^{2} \leq 0,75$ & $0,50<$ Nash $\leq 0,65$ \\
4. & Tidak memuaskan & $\mathrm{R}^{2}<0,6$ & Nash $\leq 0,5$ \\
\hline
\end{tabular}

\section{HASIL DAN PEMBAHASAN}

\section{A. Lokasi Penelitian}

Daerah aliran sungai (DAS) Air Dingin merupakan salah satu DAS yang terletak di Kecamatan Koto Tangah Kota Padang yang bermuara langsung ke samudra hindia. Secara geografis terletak pada $0^{\circ} 45^{\prime}-0^{\circ} 55^{\prime}$ Lintang Selatan dan $100^{\circ} 20^{\prime}-100^{\circ} 30^{\prime}$ Bujur Timur dan berada pada ketinggian 0 1808 mdpl, dengan luas 12477,32 ha. Topografi wilayah DAS Air dingin adalah datar, curam dan agak curam dengan kemiringan lahan $0-50 \%$ (Rahma Yanti, 2017). Batas-batas wilayah DAS Air dingin antara lain : sebelah utara berbatasan dengan DAS Batang Kandis, sebelah selatan berbatasan dengan Kuranji, sebelah barat berbatasan dengan Samudera Hindia, dan sebelah timur berbatasan dengan Kabupaten Solok seperti terlihat pada Gambar 2.

\section{B. Curah Hujan}

Curah hujan merupakan komponen utama dalam membangun model GR2M. Seperti terlihat pada Gambar 3 berikut rata-rata hujan paling tinggi terjadi pada bulan November $518 \mathrm{~mm} / \mathrm{bulan}$ dan hujan paling kecil pada bulan Juli $205 \mathrm{~mm} / \mathrm{bulan}$. 


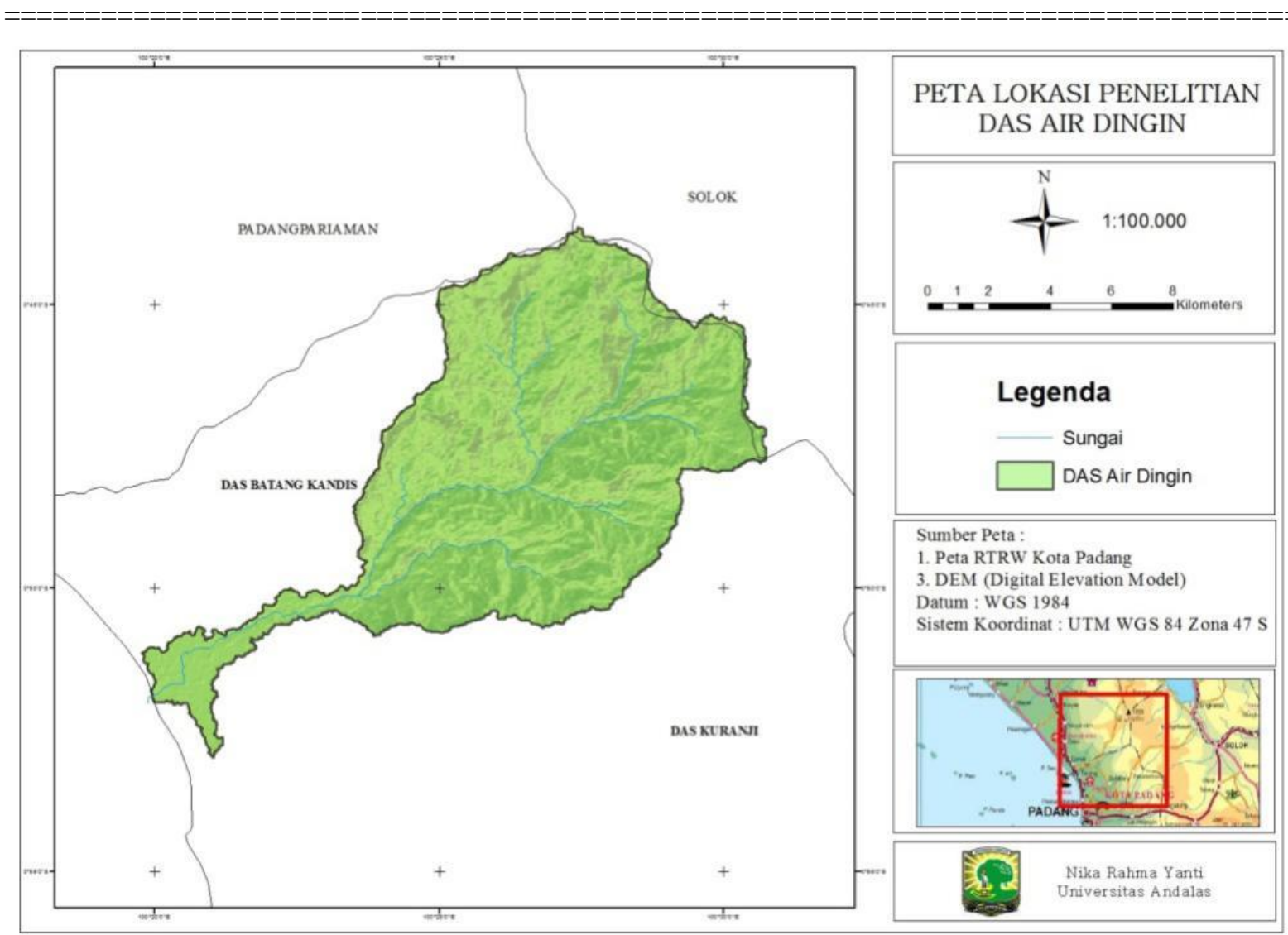

Gambar 2. Peta Lokasi Penelitian

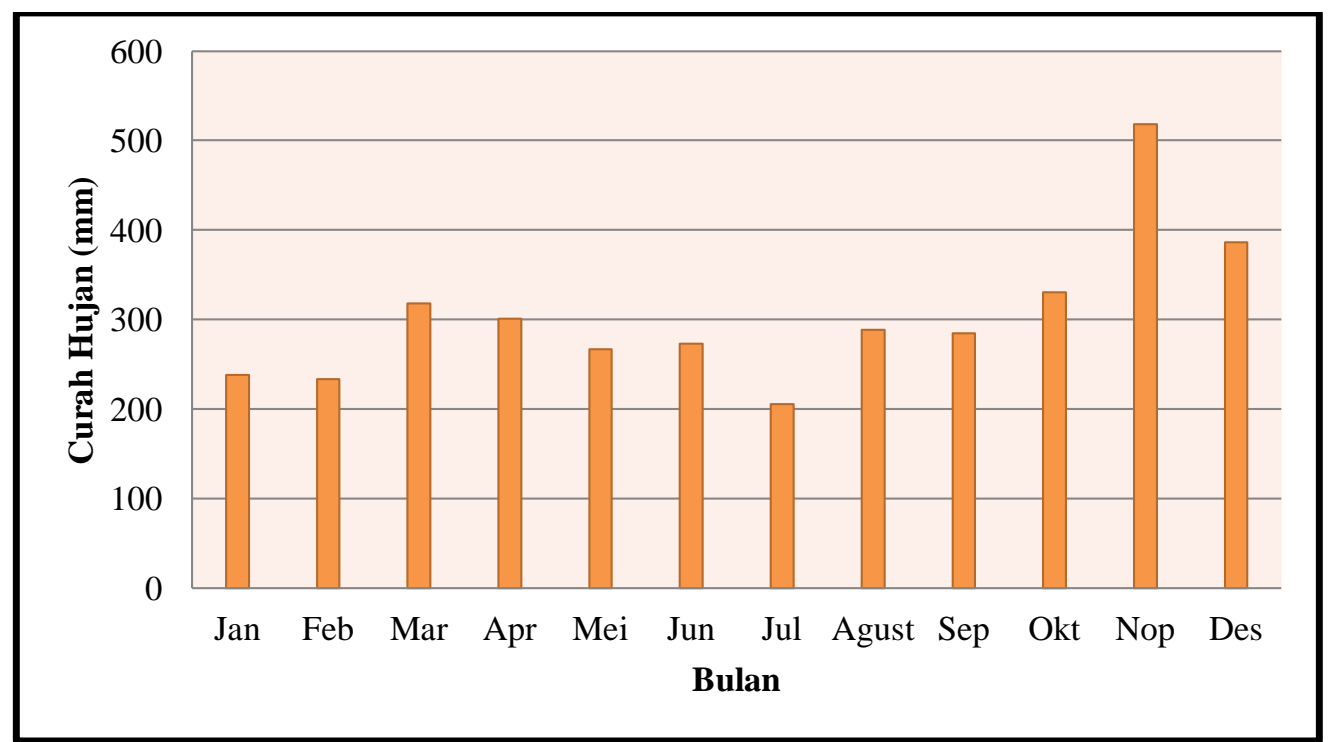

Gambar 3. Curah hujan bulanan

\section{Evapotranspirasi}

Pengolahan data evapotranspirasi bulanan didapatkan nilai rata-rata evapotranspirasi sebesar $115 \mathrm{~mm} /$ bulan, evapotranspirasi tertinggi terjadi pada bulan maret sebesar 122,8 mm/bulan, seperti terlihat pada Tabel 2 berikut. 
Tabel 2. Rekapitulasi Evapotranspirasi Bulanan (mm/bulan)

\begin{tabular}{ccccccccccccc}
\hline Tahun & Jan & Feb & Mar & Apr & May & Jun & Jul & Aug & Sep & Oct & Nov & Dec \\
\hline 2007 & 133,3 & 119,3 & 121,5 & 128,4 & 122,5 & 117,9 & 116,9 & 120,6 & 126,9 & 117,2 & 111,0 & 113,8 \\
2008 & 114,1 & 128,5 & 127,1 & 117,0 & 124,9 & 114,6 & 115,6 & 118,1 & 108,9 & 109,1 & 117,0 & 114,1 \\
2009 & 117,8 & 111,2 & 132,4 & 121,5 & 127,7 & 124,5 & 115,3 & 120,0 & 123,0 & 111,3 & 107,7 & 111,0 \\
2010 & 124,9 & 117,3 & 123,4 & 117,3 & 123,7 & 119,7 & 109,7 & 125,2 & 114,9 & 116,9 & 102,6 & 113,5 \\
2011 & 114,7 & 124,3 & 112,8 & 114,0 & 126,2 & 113,1 & 123,7 & 119,4 & 105,3 & 117,8 & 101,4 & 107,9 \\
2012 & 129,0 & 109,8 & 126,8 & 118,5 & 122,5 & 115,8 & 122,1 & 111,9 & 109,5 & 106,6 & 105,3 & 109,1 \\
2013 & 113,8 & 95,8 & 120,3 & 110,1 & 124,0 & 117,6 & 116,3 & 119,0 & 115,2 & 117,8 & 108,3 & 111,0 \\
2014 & 120,6 & 128,8 & 111,9 & 111,9 & 105,7 & 112,5 & 117,2 & 118,4 & 111,0 & 109,7 & 101,4 & 103,9 \\
2015 & 125,2 & 123,5 & 126,5 & 117,6 & 120,3 & 115,5 & 125,9 & 113,8 & 99,6 & 70,7 & 110,4 & 115,3 \\
2016 & 118,7 & 119,8 & 127,4 & 123,9 & 113,2 & 113,1 & 117,8 & 124,6 & 111,6 & 103,2 & 108,0 & 81,5 \\
2017 & 106,3 & 116,2 & 125,9 & 111,9 & 120,3 & 98,7 & 112,5 & 106,0 & 105,6 & 126,5 & 101,4 & 106,6 \\
2018 & 107,0 & 118,2 & 117,2 & 109,5 & 104,5 & 103,5 & 109,4 & 116,6 & 104,7 & 102,6 & 103,5 & 120,9 \\
\hline $\begin{array}{c}\text { Rata- } \\
\text { rata }\end{array}$ & 118,8 & 117,7 & 122,8 & 116,8 & 119,6 & 113,9 & 116,9 & 117,8 & 111,4 & 109,1 & 106,5 & 109,0 \\
\hline
\end{tabular}

Semakin tinggi evapotranspirasi semakin banyak air yang dibutuhkan oleh tanaman. Evapotranspirasi merupakan komponen penting yang mempengaruhi keseimbangan hidrologi pada suatu wilayah, hal ini disebabkan karena nilai evapotranspirasi mengandung fase air yang besar. Besaran nilai evapotranspirasi sangat penting diketahui untuk kepentingan perencanaan pengelolaan sumber daya air, sumber daya lahan dan pertanian secara umum (Supangat, 2016)

\section{Kalibrasi dan validasi model}

Kalibrasi model hidrologi didasarkan pada beberapa indikator statistik. Nash-Sutcliffe adalah salah satu kriteria referensi untuk kalibrasi persamaan (model) hidrologi. Kalibrasi dilakukan untuk melihat parameter-parameter yang sesuai dalam menggunakan model GR2M pada suatu daerah aliran sungai terutama parameter X1 (kapasitas simpanan kelembaban tanah) dan X2 (koefisien penyerapan air tanah) (Traore, 2014). Pada penelitian ini kalibrasi dilakukan terhadap 4 tahun data pertama pengamatan yakninya data debit tahun 2007 sampai 2010 seperti terlihat pada Tabel 3.

Tabel 3. Hasil Nilai Kalibrasi

\begin{tabular}{llll}
\hline Data Tahun & Parameter optimal & Kriteria & Nilai \\
\hline \multirow{2}{*}{$2007-2010$} & $\mathrm{X} 1=8,41$ & $\mathrm{R}^{2}$ & 0,7 \\
& $\mathrm{X} 2=0,15$ & Nash $(\mathrm{Q})$ & 0,710 \\
& & Nash $\sqrt{Q}$ & 0,603 \\
\hline
\end{tabular}

Berdasarkan kalibrasi yang telah dilakukan terhadap data debit observasi dan debit simulasi diperoleh nilai yang berkisar antara 0,7 ini artinya model dapat diterima dengan kategori memuaskan. Selanjutnya dilakukan validasi terhadap model GR2M yang telah dikalibrasi parameternya. Validasi model dilakukan pada data debit tahun 2011-2015.

Tabel 4. Hasil Nilai Validasi

\begin{tabular}{cll}
\hline Data Tahun & Kriteria & Nilai \\
\hline \multirow{2}{*}{$2011-2015$} & $\mathrm{R}^{2}$ & 0,67 \\
& Nash (Q) & 0,730 \\
& Nash $\sqrt{Q}$ & 0,606 \\
\hline
\end{tabular}

\section{E. Hasil Model}

Terdapat beberapa perbedaan nilai debit yang dihasilkan oleh simulasi model GR2M dan debit observasi, dalam hal ini digunakan data pengukuran debit pada stasiun pengukuran debit DAS Air Dingin. Seperti terlihat pada Gambar 4, pada tahun akhir 2017 hingga awal tahun 2018 terdapat 
perbedaan yang cukup signifikan pada hasil debit simulasi dengan data debit aktual meskipun tren naik turun grafik cendrung sama.

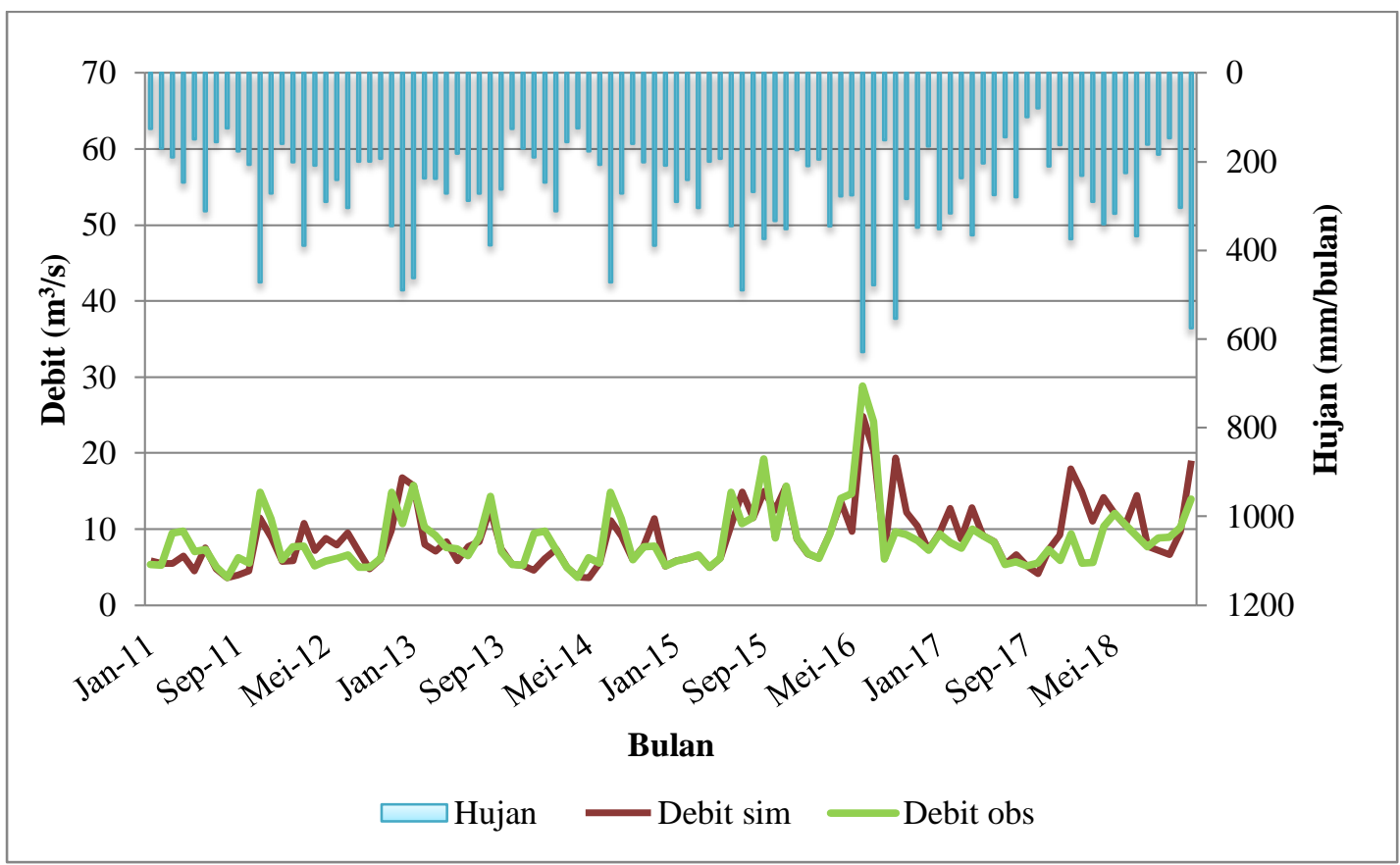

Gambar 4. Grafik Perbandingan Debit Simulasi dengan Debit Observasi

Berdasarkan grafik diatas semakin tinggi jumlah hujan maka nilai debit yang dihasilkan akan semakin tinggi. Fluktuasi nilai debit sesuai dengan pergerakan jumlah hujan pada setiap bulannya. Terdapat beberapa perbedaan nilai debit simulasi dan observasi, hal ini disebabkan karena debit simulasi yang dihasilkan oleh model tergantung kepada jumlah hujan yang terjadi.

\section{KESIMPULAN}

Berdasarkan penelitian yang telah dilakukan dapat ditarik kesimpulan sebagai berikut 1. Parameter optimal dalam menggunakan model GR2M pada DAS Air Dingin untuk X1 (kapasitas simpanan kelembaban tanah) adalah 8,41 dan X2 (koefisien penyerapan air tanah) adalah 0,15.

2. Transformasi hujan-debit model GR2M dapat mempresentasikan DAS Air Dingin. Berdasarkan hasil pengujian pada saat proses kalibrasi diperoleh performa model dengan $R^{2}=0,7$ dan Nash $(Q)$ sebesar 0,71 serta Nash $\sqrt{\mathbf{Q}}$ sebesar 0,603 dalam hal ini pengujian model dinilai memuaskan.

\section{UCAPAN TERIMAKASIH}

Penulis mengucapkan terima kasih kepada Fakultas Teknologi Pertanian Universitas Andalas sesuai dengan Surat Perjanjian Pelaksanaan Pekerjaan Penelitian No : 011/PL/DF-DIPA/FATETA2020 yang telah mendanai penelitian ini. Penulis juga mengucapkan terima kasih kepada seluruh pihak yang telah membantu terlaksananya penelitian ini.

\section{DAFTAR PUSTAKA}

Allen, R. V. 2019. Analisis Perubahan Penggunaan Lahan Daerah Aliran Sungai (DAS) Air Dingin Dan Dampaknya Terhadap Aliran Permukaan. Jurnal Teknik Pertanian Lampung (Journal of Agricultural Engineering), 8(3), 198. doi;10.23960/jtep-l.v8i3.198-207

Arifjaya, N. M., Kusmana, C., Abdulah, K., \& Prasetyo, L. B. 2012. Application of Tank Model for Predicting Water Balance and Flow Discharge Components of Cisadane Upper Catchment. Jurnal Manajemen Hutan Tropika, 17(2), 63-70. doi:10.7226/jmht.17.2.63-70 
BSN. 2004. Tata cara penghitungan evapotranspirasi tanaman acuan dengan metode PenmanMonteith. RSNI T-01, 17.

De Almeida Bressiani, D., Srinivasan, R., Jones, C. A., \& Mendiondo, E. M. 2015. Effects of different spatial and temporal weather data resolutions on the stream flow modeling of a semiarid basin, Northeast Brazil. International Journal of Agricultural and Biological Engineering, 8(3), 1-16. doi:10.3965/j.ijabe.20150803.970

Ibrahim, B., Karambiri, H., \& Polcher, J. 2015. Hydrological impacts of the changes in simulated rainfall fields on Nakanbe basin in Burkina Faso. Climate, 3(3), 442-458. doi:10.3390/cli3030442

Limantara, L. M. 2010. Hidrologi Praktis. Bandung: Penerbit Lubuk Agung.

Mouelhi, C., C. Michel., C. P. and V. A. 2006. Stepwise Development of a Two-Parameter Monthly Water Balance Model. Journal of Hydrology, 318. No. 1, 200-214. doi:10.1016/j.jhydrol.2005.06.014

Pérez-Sánchez, J., Senent-Aparicio, J., Segura-Méndez, F., Pulido-Velazquez, D., \& Srinivasan, R. 2019. Evaluating hydrological models for deriving water resources in peninsular Spain. Sustainability (Switzerland), 11(10), 1-36. doi:10.3390/su11102872

Pratiwi, D. W., Hadiani, R., \& Suyanto. 2016. Transformasi hujan-debit berdasarkan analisis Tank Model dan GR2M. E-Jurnal Matriks Teknik Sipil, 534-543.

Rahma Yanti, N., Rusnam, R., \& Ekaputra, E. G. 2017. Analisis Debit Pada Das Air Dingin Menggunakan Model Swat. Jurnal Teknologi Pertanian Andalas, 21(2), 127. doi:10.25077/jtpa.21.2.127-137.2017

Rusnam, R. 2013. Analisis Spasial Besaran Tingkat Erosi Pada Tiap Satuan Lahan Di Sub Das Batang Kandis. Jurnal Dampak, 10(2), 149. doi:10.25077/dampak.10.2.149-167.2013

Supangat, A. B. 2016. Analisis Perubahan Nilai Pendugaan Evapotranspirasi Potensial Akibat Perubahan Iklim di Kawasan Hutan Tanaman Eucalyptus pellita. Seminar Nasional Geografi UMS 2016, 112-122.

Susanto, S. 2012. Pengembangan dan Manajemen Sumberdaya Air di Wilayah Tropis. Yogyakarta: Penerbit Kanisius.

TRAORE, V. B. 2014. Calibrating the Rainfall-Runoff Model GR4J and GR2M on the Koulountou River Basin, a Tributary of the Gambia River. American Journal of Environmental Protection, 3(1), 36. doi:10.11648/j.ajep.20140301.15 